\title{
Epidural Anesthesia in Elective Lumbar Microdiscectomy Surgery: Is It Safe and Effective?
}

\author{
Elektif Lomber Mikrodiskektomi Cerrabisinde Epidural Anestezinin Yeri: \\ Güvenli ve Etkili mi?
}

\author{
Akın AKAKIN ${ }^{1}$, Baran YILMAZ ${ }^{1}$, Alp AKAY², Soner SAHIN ${ }^{3}$, Murat Sakir EKSI ${ }^{4}$, Deniz KONYA $^{1}$ \\ ${ }^{1}$ Babcesehir University, School of Medicine, Department of Neurosurgery, Istanbul, Turkey \\ ${ }^{2}$ Bahcesehir University, School of Medicine, Department of Anesthesiology, Istanbul, Turkey \\ ${ }^{3}$ Kocaeli Derince Research and Teaching Hospital, Department of Neurosurgery, Kocaeli, Turkey \\ ${ }^{4}$ University of California, San Francisco, Ortopedic Surgery-Spine Center, California, USA
}

Corresponding Author: Akın AKAKIN / E-mail: drbaranylmz2013@gmail.com

\begin{abstract}
AIM: The aim of this study was to evaluate effectiveness and safety of epidural anesthesia in elective lumbar microdiscectomy surgery.

MATERIAL and METHODS: Twenty-seven patients (78\%, female), who were admitted for single level simple microdiscectomy surgery between May 2012 and December 2013 in single spine center of a university hospital, were enrolled into the study. Clinical evaluations with demographical and per-operative data were collected prospectively.

RESULTS: Mean age was 60.04 years. Mean weight, height, and BMI of the study population were $77.7 \mathrm{~kg}, 160.22 \mathrm{~cm}, 30.26$; respectively. Mean operation duration was 45.56 minutes. Mean VAS score for pain was 0.78 at immediate post-op, 0.52 at 4 th hour, and 0.35 at post-operative $24^{\text {th }}$ hour. Ramsay sedation scale (RSS) scores steadily decreased from 2.07 in the immediate post-operative time to 1.93 at $4^{\text {th }}$ hour and 1.88 at $24^{\text {th }}$ hour. The only correlation seen between patient demographics and RSS was body weight seen in immediate post-operative period. Improvements for VAS scores for pain at $4^{\text {th }}$ and $24^{\text {th }}$ hours were $28 \%$ and $31 \%$; respectively. Three patients had nausea, one of them vomited after the surgery. All patients were satisfied and would consider epidural anesthesia in future similar surgeries.
\end{abstract}

CONCLUSION: Epidural anesthesia provides a safe and effective method for elective lumbar microdiscectomy surgery.

KEYWORDS: Regional anesthesia, Epidural anesthesia, Lumbar microdiscectomy, Neurosurgery

öz

AMAÇ: Çalışmada, elektif lomber mikrodiskektomi cerrahisinde epidural anestezinin güvenirliğini ve etkinliğini değerlendirmeyi amaçladık. YÖNTEM ve GEREÇLER: Tek seviye lomber disk hernisi tanısı ile opere edilmek üzere bir üniversite hastanesinin omurga cerrahisi merkezine Mayıs 2012 ile Aralık 2013 tarihleri arasında başvuran ve çalışmaya katılmayı kabul eden 27 hasta (\%78'I kadın) çalışmaya dahil edildi. Hastaların klinik, demografik ve per-operatif verileri prospektif olarak toplandı.

BULGULAR: Ortalama yaş 60,04 yıldı. Hastaların ortalama kilo, boy ve vücut kitle indeksleri sırasıyla 77,7 kg, 160,22 cm, 30,26'ydı. Ameliyat ortalama süresi 45,56 dakikaydı. Ağrı için VAS skoru erken post-operatif dönemde 0,78'di, post-operatif 4. saatte 0,52'ye ve 24 . saatte $0,35^{\prime}$ e düştü. Ramsay sedasyon skalası (RSS) skoru post-operatif erken dönemde 2,07'ydi, 4. saatte 1,93'e, 24. saatte 1,88'e geriledi. Hastaların demografik verileri ile RSS skorunun korelasyon içinde olduğu tek veri hasta kilosuydu. Sadece erken post-operatif dönemde bu korelasyon gözlemlendi. Dördüncü saatteki ve 24. saatteki VAS skorunda iyileşme sırasıyla \%28 ve \%31'dir. Sadece 3 hastada post-operatif izlemde bulantı oldu ve bu hastalardan biri kustu. Bunun dışında hastalarda ciddi bir komplikasyon görülmedi. Bütün hastalar epidural anestezi prosedüründen memnun olduklarını ve ileride benzer bir durumunda tekrar aynı anestezi yöntemini tercih edebileceklerini bildirdiler.

SONUÇ: Elektif lomber mikrodiskektomi cerrahisinde epidural anestezi, güvenli ve etkili bir yöntemdir.

ANAHTAR SÖZCÜKLER: Bölgesel anestezi, Epidural anestezi, Lomber mikrodiskektomi, Nöroşirürji

\section{INTRODUCTION}

There are 3 different anesthesia types: General, regional (epidural \& spinal), and local. With advancement in technology and techniques, more minimally invasive spinal surgical procedures have been developed and more minimally invasive anesthetic techniques have become popular (11). There are some factors to be considered to decide which anesthetic method is more suitable for that particular surgical procedure: type of surgical procedure, extent of the procedure, patient co-morbidities, patient's choice, and anesthetist's experience with the anesthetic technique (11).

General anesthesia is the method of choice in most lumbar microdiscectomy procedures as well as the other spinal surgeries; because of patient's choice and protected airway in a prone position (4). However, more interest has recently been given to regional anesthetic techniques for lumbar 
discectomy surgery performed under operative microscope (1). Regional anesthesia can be used for lower thoracic or lumbar spinal procedures (5). However, epidural anesthesia is safer than spinal anesthesia in cardiac and neurological aspects (11). A good anesthetic should have some properties: rapid onset, rapid arousal after cessation, stable hemodynamic profile, reduced blood transfusion need, decreased postoperative side effects (nausea, vomiting), reduced pain in the post-operative period with lesser additional narcotics $(1,5)$. Epidural anesthesia has some advantages over general anesthesia. Patient is awake and only sedated throughout the procedure, so pressure over brachial plexus and face can be prevented, fewer narcotics are needed, and other benefits are less hypertension, lesser amount of blood loss, short operation time, short post-operative recovery time, verbal communication between the patient and the surgeon to assess adequate decompression of the nerve, fewer side effects like pain, nausea, vomiting, urinary retention, headache, stress responses, thromboembolic events $(1,2,5,8$, $11,16)$. Possible complications about epidural anesthesia are anesthetic drugs can be mistakenly injected into intravascular or intradural compartments, neurological injury, urinary retention, slow onset, and shorter duration of drug effect (11).

The aim of the present study is to evaluate effect of epidural anesthesia over patients' pain sensation and sedation levels, operation time-lengths, post-operative recovery time and hospital stay length, post-operative side effects solely in elective lumbar microdiscectomy surgeries.

\section{MATERIAL and METHODS}

Patients scheduled for elective lumbar microdiscectomy surgery and consented to have epidural anesthesia $(n=27)$ were enrolled into this study from May 2012 to December 2013. Inclusion criteria were complaint of sciatica, single level lumbar intervertebral disc herniation diagnosed by clinically and radiologically. Patients with contraindications to epidural anesthesia (coagulopathy problem, local infection, prior surgery at the same level, problem with surgical position without protected airway) were excluded from the study. The Institutional Review Board of Bahceşehir University Medical Faculty approved the study protocol.

One of the authors obtained clinical histories, demographical data, made physical examinations and measured visual analog scale (VAS) scores for pain and Ramsay sedation scale (RSS) scores. Visual analog scale scores for pain and RSS scores were collected at $0,4^{\text {th }}$, and $24^{\text {th }}$ hour of the post-operative period. Visual analog scale score for pain is composed of 10 $\mathrm{cm}$ horizontal line with each centimeter representing 1 point for pain level. "0 point" means "no pain"; whereas "10 cm" corresponds to "the worst pain in the patient's experience" (9). Ramsay sedation scale is based on a scoring system of 6 . Score 1 is "anxious and agitated or restless or both"; score 2 is "cooperative, oriented, and tranquil"; score 3 is "responds to commands only", score 4 is "brisk response to a light glabellar tap or loud auditory stimulus"; score 5 is "sluggish response to a light glabellar tap or loud auditory stimulus"; score 6 is "no response to a light glabellar tap or loud auditory stimulus" (12). Additional data about time to first ambulation, time to transition from IV pain medications to oral forms, days of hospital stay, and postoperative complications including neurological pathologies (epidural hematoma, numbness, weakness or paresis), infection, cardiac failure (arrhythmia, severe hypotension), urinary retention; were also collected. Patients were asked about their satisfaction with epidural anesthesia before their discharge to home.

A staff anesthesiologist supervised management of the analgesic regimens. Patients receiving epidural anesthesia were given a single injection of $20-30$ cc of $2 \%$ lidocaine with epinephrine (diluted in 1:200.000 ratio) and 100 microgram of fentanyl minimum two levels above the surgical site with propofol (100-200 $\mathrm{mg}$ ) and midazolam (5-10 mg) as sedatives as described by Papadopoulos et al (11). Epidural injections were done at a single level between T12-L5, with the majority administered between L2-L3 and L3-L4 levels. No dural puncture happened and no cases were converted to general anesthesia. The epidural catheter was left in place to supply additional anesthesia for an unexpected prolongation of the procedure. All patients were positioned in prone position with their heads turned to anesthesia side. Before onset of sedation, sensorial levels were checked with the pinprick test (1). All patients were monitored with continuous electrocardiography, blood pressure, respiratory rate, peripheral oxygen saturation, end-tidal anesthetic gas and end-tidal $\mathrm{CO}_{2}$ concentration (1). All patients' hemodynamic status was stable. Venous air embolism was monitored and did not occur in any patient. Patients were given $\mathrm{O}_{2}$ with nasal cannula at a rate of $2 \mathrm{~L} / \mathrm{min}$ throughout the operation and immediate post-operative follow-up.

Correct intervertebral disc levels were confirmed with intraoperative C-arm fluoroscopic images, and operative microscope was used for all operations.

Descriptive statistics were used for description of data. Categorical variables were presented with frequencies and percentages. Continuous variables with a normal distribution were described with mean and standard deviation (SD). Linear regression was used to find out predictive variables for VAS score for pain and RSS score changes in post-operative period. Statistical Package for Social Sciences version 22 (SPSS v.22, IBM, New York, USA) was used for statistical analysis and an alpha value of $<0.05$ was expected for statistically significant difference.

\section{RESULTS}

Twenty-one of the patients (78\%) were female. Mean age was 60.04 years $(S D=10.639$ years; range $=40-85$ years). Mean weight, height, and body mass index (BMI) of the study population were $77.7 \mathrm{~kg}(\mathrm{SD}=11.282 \mathrm{~kg}$, range=51-98 kg), 160.22 $\mathrm{cm}(\mathrm{SD}=9.167 \mathrm{~cm}$, range $=146-180 \mathrm{~cm})$ and $30.26(\mathrm{SD}=4.3733$; range $=23-41)$, respectively. Mean operation duration was 45.56 minutes ( $S D=10.860$ minutes; range $=25-65$ minutes). Mean value of VAS score for pain was $0.78(S D=1.013)$ at imme- 
diate post-operative period. It decreased to $0.52(S D=0.975)$ at $4^{\text {th }}$ hour of operation and then to $0.35(S D=0.689)$ at postoperative $24^{\text {th }}$ hour. Ramsay sedation scale scores steadily decreased from $2,07(S D=0.550)$ in the immediate post-operative time to $1,93(S D=0.385)$ at $4^{\text {th }}$ hour and $1,88(S D=0.326)$ at $24^{\text {th }}$ hour of operation.

Patients' genders, weights, and BMIs were statistically studied for a possible correlation with VAS scores for pain and RSS scores at immediate post-operative, post-operative $4^{\text {th }}$ and $24^{\text {th }}$ hour time-points. However, there was no significant correlation between gender, weight, BMI and VAS scores at any time point $(r=-0.149 ; 0.176 ; 0.125$ with $p$ values $=0.229$; $0.190 ; 0.272$ for gender; $r=-0.023 ;-0.006 ; 0.204$ with $p$ values $=0.455 ; 0.487 ; 0.159$ for weight; $r=-0.004 ;-0.015 ; 0.283$ with $\mathrm{p}$ values $=0.492 ; 0.471 ; 0.080$ for $\mathrm{BMl}$; respectively at 0 . $4^{\text {th }}$, and $24^{\text {th }}$ hours post-operatively). There was no correlation between gender and RSS scores $(r=0.257 ; 0.105 ; 0.198$ with $p$ values $=0.098 ; 0.301 ; 0.166$ respectively at $0.4^{\text {th }}$, and $24^{\text {th }}$ hours post-operatively). When looking for a correlation between BMI and RSS scores, we did not find a significant correlation either $(r=-0.248 ;-0.080 ; 0.004$ with $p$ values $=0.106 ; 0.347 ; 0.492$ respectively at $0.4^{\text {th }}$, and $24^{\text {th }}$ hours post-operatively) however, patient weight was significantly negatively correlated with RSS scores at immediate post-operative period $(r=-0.455$; $p=0.008$ ), which could not be observed at other time points $\left(r=0.119 ; 0 / 237\right.$ with $p$ values $=0.278$; and 0.122 at $4^{\text {th }}$ and $24^{\text {th }}$ hours after the operations). Improvements for VAS scores for pain at $4^{\text {th }}$ and $24^{\text {th }}$ hours were $28 \%$ and $31 \%$, respectively. There was a strong significant positive correlation between improvements in VAS score for pain at $4^{\text {th }}$ hour and $24^{\text {th }}$ hour time-points $(r=0.856 ; p=0.000)$.

All patients were ambulated within 24 hour after the operation. Neither any neurological deficit nor urinary retention was observed in any patient. Only 7 patients needed additional analgesic control with NSAID during post-operative 24-hour follow-up in the hospital. After $1^{\text {st }}$ day of surgery, all patients' pain management turned to oral medication form. Three patients had nausea (11\%), one of them vomited $(3.7 \%)$ in the early post-operative follow-up. There was no complication like epidural hematoma, infection or cardiopulmonary event during short- and long-term follow-up of these patients. All patients mentioned that they were satisfied with epidural anesthesia and would like to have the same type of anesthesia in the future similar surgeries.

\section{DISCUSSION}

General anesthesia is the conventional method in use for lumbar microdiscectomy and other spinal surgeries. In modern era of surgery both spinal and epidural anesthesia are becoming more popular (1, 5, 11, 14, 16). Although spinal anesthesia is a successful regional anesthesia method, additional doses cannot be applied such as can be done in epidural anesthesia (3). Other advantages of epidural anesthesia over general anesthesia are lower blood losses, less need for parenteral narcotics, lower incidence of urinary retention, less operation time, verbal communication of surgeon and the patient during the operation to assess adequacy of decompression, self-positioning of the patient to avoid pressure over brachial plexus or other pressure points, less hypertension episodes, less post-operative pain, nausea and less time to arousal from sedation $(1,2,5,8,11$, 16). Less blood loss and hypotension are due to sympathetic blockage and more inhibition of surgically induced stress hormones through epidural anesthesia $(1,6,7,15,17)$. Less blood loss also facilitates surgery and lessens operation time (1). Operation time was $<1$ hour in this study. Disadvantages are headache, urinary retention, and short duration of action (8). Papadopoulos et al., found no significant differences between general and epidural anesthesia about surgical and anesthesia times, duration of hospital stay, and time to ambulate (11). Nausea and vomiting were significantly lesser in the epidural group. Only one patient had nausea (3.7\%) (11). In this study, $11 \%$ of the patients had nausea and one of them (3.7\%) vomited in the 24 hour of post-operative followup period.

Visual analog scale score for pain was not found to be significantly different between general and epidural anesthesia techniques (11). In our study, we used only the epidural anesthesia technique. Although, we did not have a chance to compare the two groups of anesthesia technique, we observed that VAS score for pain was dramatically low at the immediate post-operative period $(0.78)$ and decreased to 0.35 after 24 hour of operation. There was a strong positive correlation between improvement in VAS score for pain after 4 hour and improvement in VAS score for pain after 24 hour, meaning if a patient's VAS score for pain was good in the $4^{\text {th }}$ post-operative hour, this would continue to the $24^{\text {th }}$ hour of the post-operative period.

In this study, we observed no peri- or post-operative complications except nausea and vomiting in our small number of patients. This could be due to relatively healthy study population and elective nature of the surgeries. Postoperative analgesia and incidence of nausea and vomiting are less in regional anesthesia $(1,5,11)$. Decreased nausea is due to decreased need for narcotics that sensitize the vestibular apparatus, the absence of $\mathrm{N}_{2} \mathrm{O}$ given in general anesthesia and the low level (T8 or lower) central neuroaxial blockade in epidural anesthesia which conveys gastric emptying $(10,13)$. In our study, we also evaluated RSS scores in the first 24 hours after the operation. According to observed scores in immediate post-operative time and afterwards (2.07 at immediate post-operative time; 1.93 at $4^{\text {th }}$ hour; 1.88 at $24^{\text {th }}$ hour), sedation levels recovered well with a smaller amount of agitation. Both reduced VAS scores for pain and normal RSS scores make the patients and their relatives satisfied with the procedure with less anxiety. Patients also mentioned that they were satisfied with the anesthesia type and would choose the same type of anesthesia in the future for similar operations, which is consistent with prior studies in the literature (1).

There are some limitations of this study. This study included only patients operated under epidural anesthesia with a small 
sample size. It is hard to make a conclusion about differences between epidural anesthesia and general anesthesia. Statistical analysis would be stronger with a large cohort. This study can be evaluated as a preliminary study giving some ideas about advantages and side effects of epidural anesthesia performed for elective lumbar microdiscectomy surgeries.

\section{CONCLUSION}

Epidural anesthesia provides a safe and effective lumbar microdiscectomy surgery with minimal post-operative pain and maximal satisfaction for the patient. More comparative, randomized prospective studies should be conveyed to make more general statements and make the procedure primary method in daily practice.

\section{REFERENCES}

1. Demirel CB, Kalayci M, Ozkocak I, Altunkaya H, Ozer Y, Acikgoz $\mathrm{B}$ : A prospective randomized study comparing perioperative outcome variables after epidural or general anesthesia for lumbar disc surgery. J Neurosurg Anesthesiol 15:185-192, 2003

2. Greenbarg PE, Brown MD, Pallares VS, Tompkins JS, Mann NH: Epidural anesthesia for lumbar spine surgery. J Spinal Disord 1:139-143, 1988

3. Hassi N, Badaoui R, Cagny-Bellet A, Sifeddine S, Ossart M: Spinal anesthesia for disk herniation and lumbar laminectomy. Apropos of 77 cases. Cah Anesthesiol 43:21-25, 1995

4. Horlocker TT, Cucchiara RF, Ebersold MJ: Vertebral column and spinal cord surgery. In: Cucchiara RF, Michenfelder JD (eds), Clinical neuroanesthesia. New York: Churchill Livingstone, 1990:325-350

5. Jellish WS, Thalji Z, Stevenson K, Shea J: A prospective randomized study comparing short- and intermediate-term perioperative outcome variables after spinal or general anesthesia for lumbar disk and laminectomy surgery. Anesth Analg 83:559-564, 1996
6. Kakiuchi M: Reduction of blood loss during spinal surgery by epidural blockade under normotensive general anesthesia. Spine (Phila Pa 1976) 22:889-894, 1997

7. Kehlet $\mathrm{H}$ : Manipulation of the metabolic response in clinical practice. World J Surg 24:690-695, 2000

8. Matheson D: Epidural anaesthesia for lumbar laminectomy and spinal fusion. Can Anaesth Soc J 7:149-157, 1960

9. McCormack HM, Horne DJ, Sheather S: Clinical applications of visual analogue scales: A critical review. Psychol Med 18: 1007-1019, 1988

10. Nimmo WS, Littlewood DG, Scott DB, Prescott LF: Gastric emptying following hysterectomy with extradural analgesia. Br J Anaesth 50:559-561, 1978

11. Papadopoulos EC, Girardi FP, Sama A, Pappou IP, Urban MK, Cammisa FP Jr: Lumbar microdiscectomy under epidural anesthesia: A comparison study. Spine J 6:561-564, 2006

12. Ramsay MA, Savege TM, Simpson BR, Goodwin R: Controlled sedation with alphaxalone-alphadolone. Br Med J 2:656-659, 1974

13. Riding JE: Minor complications of general anaesthesia. $\mathrm{Br} \mathrm{J}$ Anaesth 47:91-101, 1975

14. Rung GW, Williams D, Gelb DE, Grubb M: Isobaric spinal anesthesia for lumbar disk surgery. Anesth Analg 84:11651166, 1997

15. Smeets HJ, Kievit J, Dulfer FT, van Kleef JW: Endocrine-metabolic response to abdominal aortic surgery: A randomized trial of general anesthesia versus general plus epidural anesthesia. World J Surg 17:601-606; discussion 606-607, 1993

16. Smrcka M, Baudysova O, Juran V, Vidlak M, Gal R, Smrcka V: Lumbar disc surgery in regional anaesthesia--40 years of experience. Acta Neurochir (Wien) 143:377-381, 2001

17. Wadsworth R, Anderton JM, Vohra A: The effect of four different surgical prone positions on cardiovascular parameters in healthy volunteers. Anaesthesia 51:819-822, 1996 